\title{
EFFECT OF LEUKOCYTE AND SYNOVIAL MEMBRANE EXTRACTS ON CARTILAGE MUCOPROTEIN *
}

\author{
By MORRIS ZIFF, $\dagger$ H. JOEL GRIBETZ $\ddagger$ AND JOSEPH LOSPALLUTO $\dagger$ \\ (From the Department of Medicine and Rheumatic Diseases Study Group, New York \\ University College of Medicine, Nerv York, N. Y.)
}

(Submitted for publication August 3, 1959; accepted October 15, 1959)

The relatively simple composition of hyaline cartilage $(1,2)$ offers a unique opportunity to investigate the mechanism of erosion of this tissue in the presence of inflammatory synovitis. Shatton, Schubert and Malawista $(1,2)$ have shown that about half of the dry weight of bovine nasal cartilage consists of chondromucoprotein material. A protein preparation of similar composition has been isolated from human rib cartilage (3). The other half of dried cartilage consists mainly of collagen (2). In the absence of evidence of an enzyme that can attack native collagen at physio$\operatorname{logical} \mathrm{pH}$, it appeared logical to investigate the possibility that the primary process occurring during the erosion of cartilage was the degradation of the chondromucoprotein. Accordingly, the effect of extracts of leukocytes and inflamed synovial membrane on the chondromucoprotein was studied.

Chondromucoprotein as extracted by Shatton and Schubert (1) contains about 70 per cent chondroitin sulfate and 30 per cent protein. It is water-soluble and highly viscous in solution. The latter property is in contrast to that of free chondroitin sulfate, which forms solutions of relatively low viscosity. On the basis of this difference, the rate of breakdown of the mucoprotein under the influence of cell-free extracts of leukocytes from the peripheral blood and of synovial membranes from patients with a variety of arthritides has been measured. Rapid decrease in viscosity on treatment with extracts of normal leukocytes and rheumatoid synovial membranes has been observed. This has been paralleled by chemical evidence of degradation of the chondromucoprotein. It is suggested on the basis of the data obtained that the

* This investigation was supported by Grant A-679 from the National Institute of Arthritis and Metabolic Diseases, Bethesda, Md.

† Present address: University of Texas Southwestern Medical School, Dallas, Texas.

$\ddagger$ Present address: Montefiore Hospital, New York, N. $Y$. dissolution of cartilage in rheumatoid arthritis and in other inflammatory arthritides occurs as a result of this process.

Shatton and Schubert (1) and Muir (4) have shown that crystalline trypsin and papain, respectively, reduce the viscosity of chondromucoprotein preparations in vitro. The results reported in the present paper have been previously published in abstract form (5).

\section{METHODS}

Chondromucoprotein. ${ }^{1}$ This was prepared from bovine nasal cartilage by the method of Shatton and Schubert (1).

Leukocyte extracts. Pellets of leukocytes obtained from the peripheral blood of normal subjects and of hospitalized patients with a normal peripheral blood picture were prepared by the addition of 1 vol of 6 per cent dextran solution to 3 vol of heparinized blood distributed in $15 \mathrm{ml}$ conical centrifuge tubes. After allowing them to stand for 1 hour at $37^{\circ} \mathrm{C}$, the supernatants were removed and centrifuged. The pellet obtained from $60 \mathrm{ml}$ of heparinized blood was taken up in $2 \mathrm{ml}$ of distilled water and alternately frozen and thawed 10 times using an ice-salt bath. The mixture was then ground in a small glass homogenizer and centrifuged. The clear pink supernatant was brought to a volume of $3 \mathrm{ml}$.

Synovial membrane extracts. Synovial membrane was obtained through the cooperation of Dr. R. L. Preston from patients with rheumatoid arthritis, ankylosing spondylitis, and osteoarthritis of the hip and knee, who were undergoing joint surgery. The fresh synovial tissue was minced with scissors in the cold. Approximately $2.5 \mathrm{~g}$ of minced tissue was homogenized in $2.5 \mathrm{ml}$ of water using a glass homogenizer. The homogenate was then alternately frozen and thawed 10 times using an ice-salt mixture and cleared by centrifugation.

$V$ iscosity measurements. Four $\mathrm{ml}$ of a 0.5 per cent solution of the chondromucoprotein in neutral salinephosphate buffer $(0.075 \mathrm{M}$ sodium chloride and $0.075 \mathrm{M}$ phosphate) was pipetted into a $4 \mathrm{ml}$ Ostwald viscosimeter placed in a water bath at $37^{\circ} \mathrm{C}$. Following a period of 15 minutes for temperature equilibration, $0.1 \mathrm{ml}$ of leukocyte or synovial membrane extract was added, the solu-

1 We are indebted to Dr. Maxwell Schubert for a number of samples of bovine and human chondromucoprotein. 
tion was rapidly mixed and viscosity readings were made at fixed time intervals. Measurements were carried on for periods of 2 to 5 hours. Per cent decrease in relative viscosity was calculated according to the formula: per cent decrease $=\left(\mathrm{T}_{0}-\mathrm{T} / \mathrm{To}_{\mathrm{o}}\right) \times 100$, where $\mathrm{To}_{\mathrm{s}}$ was the initial time of fall in seconds and $T$ the time of the experimental period. In some experiments, per cent initial relative viscosity was calculated.

Separation of lymphocytes from granulocytes of the peripheral blood. Lymphocytes were separated by the lucite plastic cylinder method of Kline (6). Forty to 60 $\mathrm{ml}$ of heparinized whole blood was taken for the usual preparation and from 0.4 to $1.5 \mathrm{ml}$ of lymphocyte suspension was obtained. Following total and differential cell counts, the lymphocyte suspension was alternately frozen and thawed 10 times and the resulting cleared extract assayed for viscosity-reducing activity. In some experiments, the lymphocytes were separated from the suspension by centrifugation, washed twice with saline, suspended in distilled water $(0.5$ to $2 \mathrm{ml})$ and alternately frozen and thawed 10 times to prepare an active extract.

The sediment of erythrocytes and granulocytes was resuspended in the supernatant plasma and, after addition of dextran, the granulocytes were isolated in the usual manner. The pellet of granulocytes was washed twice with saline and total and differential cell counts were performed on the saline suspension. The latter was then centrifuged and the resulting pellet taken up in 0.5 to 2 $\mathrm{ml}$ of distilled water. The suspension was frozen and

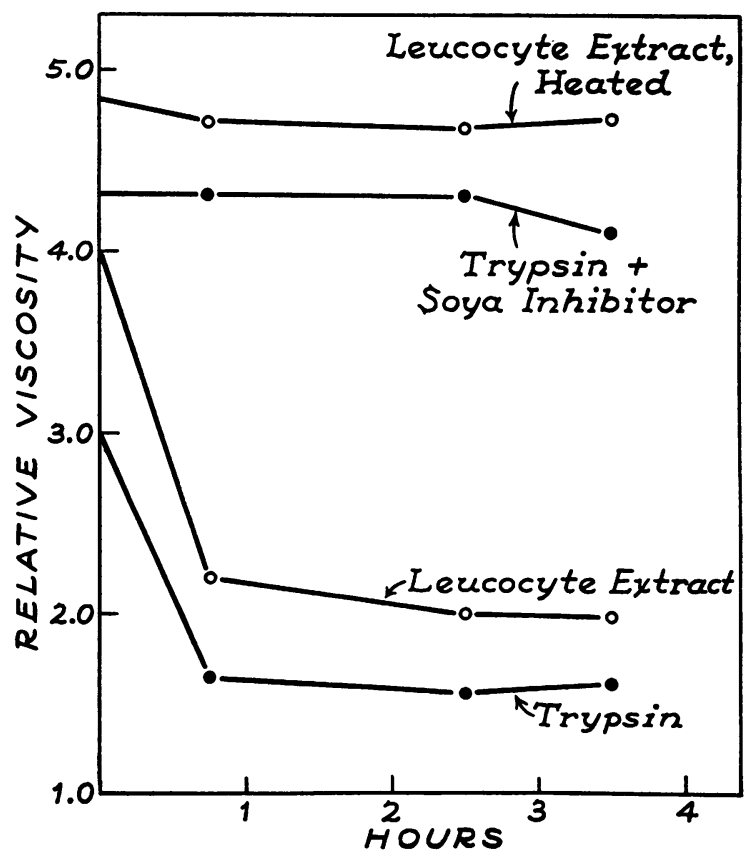

Fig. 1. EFfect of LeUkocyte extract ( 0.19 Mg N PER ML) AND TRYPSIN ( 0.005 MG N PER ML) ON VISCOSITY OF CHONDROMUCOPROTEIN. The action of trypsin was blocked by $5 \mathrm{mg}$ of soya bean inhibitor. thawed 10 times and the resulting extract assayed for viscosity-reducing activity. Microscopic examination of extracts so prepared showed no intact cells in either the lymphocyte or granulocyte fractions.

Hexosamine was determined by the method of Elson and Morgan as modified by Schloss (7).

Formol titration was carried out according to the method of Northrop (8).

Crystalline trypsin was obtained from Worthington Biochemicals Corporation.

\section{RESULTS}

Reduction of viscosity. An extract of normal leukocytes reduced the relative viscosity of a chondromucoprotein solution approximately 50 per cent in one hour (Figure 1). A similar change was induced by crystalline trypsin. Although the activity of the trypsin was blocked by the addition of soya bean inhibitor, that of the leukocyte extract was not affected. The activity of the latter, however, was destroyed by heating in a boiling water bath for five minutes.

In Figure 2 is shown the activity of an extract of a rheumatoid synovial membrane. The activity of a leukocyte extract is given for comparison. It is seen that at the same nitrogen concentration, the synovial membrane extract was about twice as active as the leukocyte extract. Both were inactive

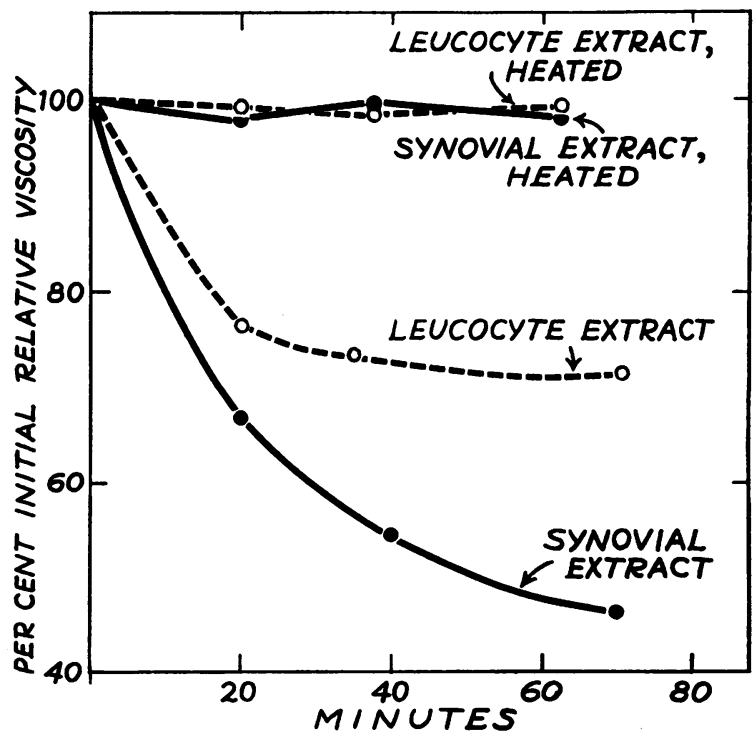

Fig. 2. EFFECT OF EXTRACTS OF RHEUMatoId SYNOVIal MEMBRANE AND LEUKOCYTES ON THE VISCOSITY OF CHONDROMUCOPROTEIN. Synovial extract, $0.072 \mathrm{mg} \mathrm{N}$ per $\mathrm{ml}$; leukocyte extract, $0.069 \mathrm{mg} \mathrm{N}$ per $\mathrm{ml}$. 
following heating. The viscosity-reducing effect of the leukocyte extract was proportional to its concentration (Figure 3 ). The activity of the leukocyte extract increased approximately twofold for a $10^{\circ}$ rise in temperature $\left(27.5^{\circ}\right.$ to $37.5^{\circ}$ C) while that of the synovial extract increased approximately 35 per cent under the same circumstances. The susceptibility of the chondromucoprotein substrate to both extracts was not changed after heating the former at $65^{\circ} \mathrm{C}$ for 20 minutes.

To investigate the effect of $\mathrm{pH}$ on activity, a leukocyte extract was added to solutions of chondromucoprotein in $0.01 \mathrm{M}$ phosphate-citrate buffer of varying $\mathrm{pH}$. Maximum reduction of viscosity measured after one hour was observed in the region of $\mathrm{pH} 6.7$ (Figure 4).

The rate of decrease of viscosity was not influenced by the addition of $0.1 \mathrm{ml}$ of the following : 1 per cent ascorbic acid, cysteine or sodium sulfide solutions; 0.5 per cent crystalline hemoglobin and crystalline serum albumin solutions; or normal serum. The viscosity-reducing effect was completely inhibited by $0.05 \mathrm{ml}$ of $0.1 \mathrm{M}$ mercuric chloride solution but not significantly by the same concentration of copper sulfate, zinc chloride, manganous sulfate or cobalt chloride.

When $1.5 \mathrm{~g}$ samples of fresh rabbit spleen were ground in a glass homogenizer with $7.2 \mathrm{ml}$ of water, physiological saline and 5 per cent saline, respectively, the resulting extracts showed no activity. Nor was activity obtained with extracts of mouse spleen, kidney, liver, or lung when $300 \mathrm{mg}$ of each tissue was minced, homogenized in $2 \mathrm{ml}$ of water, and cleared by centrifugation. The nitrogen concentration of the above extracts varied between 0.11 and $1.0 \mathrm{mg}$ per $\mathrm{ml}$.

The viscosity of a 0.5 per cent solution of sodium hyaluronate was unaffected by a leukocyte extract.

Proteolysis measured by formol titration. To determine the per cent hydrolysis of the chondromucoprotein, formol titrations were performed on this protein following incubation with a leukocyte extract, with an extract of rheumatoid synovial membrane, and with trypsin. In these experiments, $120 \mathrm{mg}$ of chondromucoprotein was incubated with appropriate amounts of the active extracts for one hour in the usual manner. Viscosity falls of 50 to 55 per cent were recorded during this period in each case (Table I). Neutralized formalin was then added and the formol titration carried

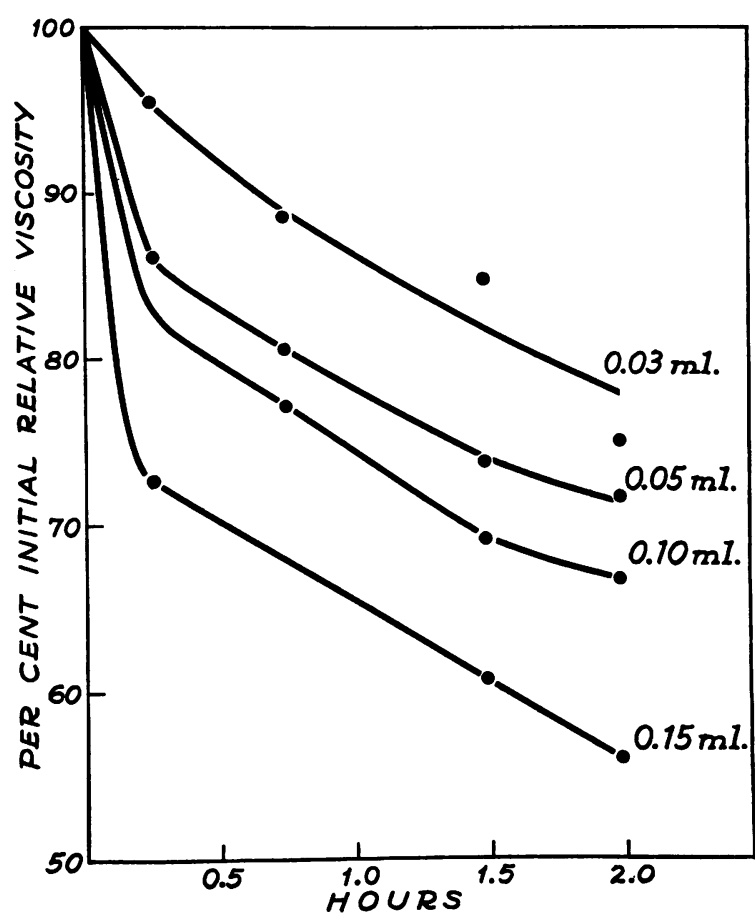

Fig. 3. EFFECT OF INCREASING CONCENTRATION OF LEUKOCYTE EXTRACT (1.2 MG N PER ML) ON VISCOSITY OF CHONDROMUCOPROTEIN.

out. The amount of the total nonhexosamine nitrogen liberated was small in all three cases, i.e., between 0.63 and 2.5 per cent. Thus the large falls in viscosity recorded were associated with a

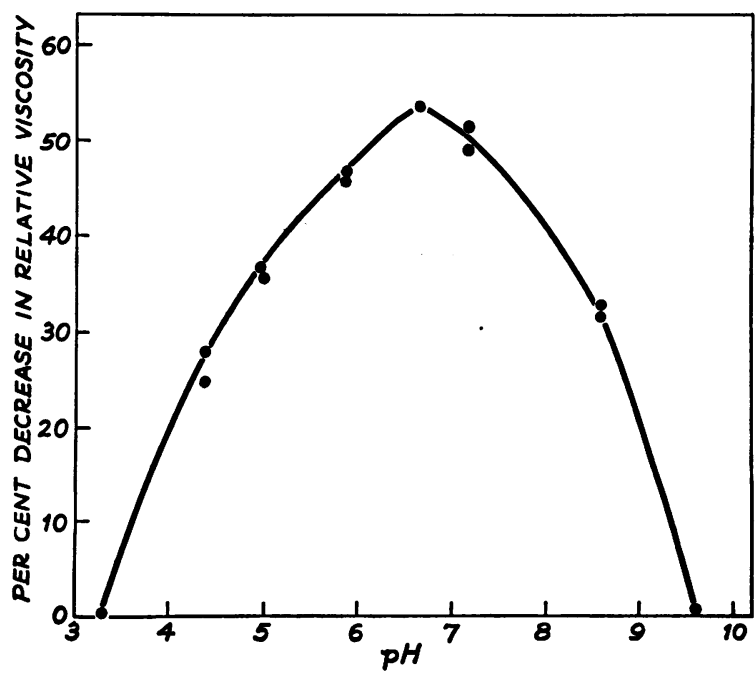

Fig. 4. EFFECT of PH ON ACtivity OF LEUkocyte exTRACT. Per cent decrease in relative viscosity is measured after one hour. Buffer is $0.01 \mathrm{M}$ phosphate-citrate; leukocyte extract concentration, $1.2 \mathrm{mg} \mathrm{N}$ per $\mathrm{ml}$. 
TABLE I

Nonhexosamine nitrogen liberated after one hour, determined by formol titration

\begin{tabular}{lcc}
\hline Enzymatic agent & $\begin{array}{c}\text { Decrease in } \\
\text { relative } \\
\text { viscosity }\end{array}$ & $\begin{array}{c}\text { Nitrogen } \\
\text { liberated }\end{array}$ \\
\hline Synovial extract & $\%$ & $\%$ \\
Leukocyte extract & 55 & 0.74 \\
Trypsin & 50 & 0.63 \\
& 50 & 2.5 \\
\hline
\end{tabular}

minimal amount of cleavage of the protein portion of the chondromucoprotein.

Degradation of chondromucoprotein. In an effort to separate the products of digestion of the chondromucoprotein, they were filtered on fritted glass bacterial funnels using the method of Ogston and Stanier (9) as applied by Shatton and Schubert. To each of two $50 \mathrm{ml}$ samples of a 0.5 per cent solution of chondromucoprotein in neutral, saline-phosphate buffer, $1 \mathrm{ml}$ of unheated and heat-inactivated leukocyte extract was added, respectively. Appropriate control solutions of mucoprotein and leukocyte extract alone were also prepared. The four solutions were incubated at $37^{\circ}$ for 170 minutes. During this time, the solution containing mucoprotein and unheated leukocyte extract showed a 50 per cent fall in viscosity. There was no significant change in the viscosities of the control solutions. All were then poured onto fritted glass filters, covered with several drops of toluene and filtered with suction for three days in a cold room at $4^{\circ} \mathrm{C}$. The filtrates were evaporated to dryness on a water bath at $70^{\circ}$ to $80^{\circ} \mathrm{C}$

TABLE II

Composition of products after treatment of chondromucoprotein* with leukocyte extract

\begin{tabular}{ccccc}
\hline & & & \multicolumn{2}{c}{ N/hexosamine } \\
\cline { 4 - 5 } Agent & $\begin{array}{c}\text { Nitrogen } \\
\text { filtered }\end{array}$ & $\begin{array}{c}\text { Hexos- } \\
\text { amine } \\
\text { filtered }\end{array}$ & $\begin{array}{c}\text { Non- } \\
\text { filterable } \\
\text { fraction }\end{array}$ & $\begin{array}{c}\text { Filter- } \\
\text { able } \\
\text { fraction }\end{array}$ \\
\hline Leukocyte extract & $19.7 \dagger$ & 3.8 & 3.0 & 20.0 \\
$\begin{array}{c}\text { Inactivated leuko- } \\
\text { cyte extract }\end{array}$ & 1.6 & 0.2 & 4.0 & \\
$\begin{array}{c}\text { Phosphate buffer } \\
\text { (pH 7.1) }\end{array}$ & 1.5 & 0.1 & 3.9 &
\end{tabular}

$* \mathrm{~N}$ to hexosamine ratio $=3.9$.

$\dagger$ Of the nitrogen which was filtered, 33.4 per cent was dialyzable. Nitrogen to hexosamine ratio of the nondialyzable residue was $\mathbf{1 6 . 4}$. and the dry residues were redissolved in $25 \mathrm{ml}$ of neutral buffer. Ten $\mathrm{ml}$ of the solutions thus obtained were dialyzed for three days against running tap water. The residues remaining on the fritted glass funnels were redissolved in $50 \mathrm{ml}$ of buffer solution. Filtrates, residues, and dialyzed filtrates were analyzed for nitrogen and hexosamine content (Table II).

A similar experiment was carried out, using trypsin instead of leukocyte extract. To $50 \mathrm{ml}$ volumes of chondromucoprotein solution, $0.1 \mathrm{mg}$ quantities of active and inactivated crystalline trypsin in $0.1 \mathrm{ml}$ of water were added, respectively. Inactivated trypsin was obtained by heating at $100^{\circ} \mathrm{C}$ for eight minutes. Following $165 \mathrm{~min}-$

TABLE III

Composition of products after treatment of chondromucoprotein* wilh trypsin

\begin{tabular}{lcccc}
\hline & & \multicolumn{2}{c}{ N/hexosamine } \\
\cline { 4 - 5 } Agent & $\begin{array}{c}\text { Nitrogen } \\
\text { filtered }\end{array}$ & $\begin{array}{c}\text { Hexos- } \\
\text { amine } \\
\text { filtered }\end{array}$ & $\begin{array}{c}\text { Non- } \\
\text { filterable } \\
\text { fraction }\end{array}$ & $\begin{array}{c}\text { Filter- } \\
\text { able } \\
\text { fraction }\end{array}$ \\
\hline $\begin{array}{l}\% \\
\text { Trypsin }\end{array}$ & $\begin{array}{c}\% \\
\%\end{array}$ & 3.73 & 3.1 & 26.8 \\
$\begin{array}{l}\text { Inactivated } \\
\text { trypsin }\end{array}$ & 0 & 0.36 & 4.1 & \\
$\begin{array}{c}\text { Phosphate buffer } \\
\text { (pH 7.1) }\end{array}$ & 0.82 & 0.23 & 4.0 & \\
\hline
\end{tabular}

$* \mathrm{~N}$ to hexosamine ratio $=4.0$.

+ Of the nitrogen filtered, 47 per cent was dialyzable. Nitrogen to hexosamine ratio of the nondialyzable residue was 14.2 .

utes, the solution containing active trypsin showed a 47 per cent fall in viscosity. Subsequent details are the same as in the experiment with leukocyte extract. Results are given in Table III.

It is apparent that treatment with both leukocyte extract and trypsin liberated a filterable fraction containing 20 to 25 per cent of the total nitrogen of the chondromucoprotein and only 3.8 per cent of the hexosamine. This fraction was markedly richer in nitrogen than the original substrate, the nitrogen to hexosamine ratio rising from approximately 4.0 to 20 and 26.8 , respectively, in the case of leukocyte extract and trypsin. A very significant fraction, 33 and 47 per cent, respectively, of the nitrogen filtered was dialyzable. The nondialyzable portion of the filtered fraction continued, 
nevertheless, to have a markedly increased ratio of nitrogen to hexosamine. The nonfilterable residues in both cases demonstrated, as would be expected, a lower nitrogen to hexosamine ratio than the starting substrate.

Effect of synovial membrane extracts on chondromucoprotein. Ten synovial membranes were extracted, four from patients with rheumatoid arthritis, one from a patient with ankylosing spondylitis, and the remainder from individuals with degenerative joint disease. The tissues were sectioned and graded for intensity of cellular infiltration on a 1-plus to a 4-plus basis by Dr. Norman Copper of the Department of Pathology. A comparison between grade of infiltration and corresponding viscosity-reducing activity of the synovial membrane extracts is given in Table IV. It is seen that there is good correlation between the activity of the extracts and the intensity of the inflammatory reaction. Activity was shown only by the three extracts of synovial membranes from patients with rheumatoid arthritis, which were graded either 2-plus or 3-plus. Minimal or no activity was shown by the other extracts, which had negligible infiltration. This was true of all the samples from the patients with degenerative joint disease.

Activity of granulocytes and lymphocytes. Experiments were carried out to establish the relative activity of these leukocyte fractions, using the swimmer technique of Kline (6) to separate them.

It is apparent from the data presented in Table $\mathrm{V}$ that extracts prepared from granulocyte-rich fractions are active, whereas those prepared from lymphocyte-rich fractions do not show activity. The data, especially those of Experiment II, strongly suggest that not only are extracts of lymphocytes themselves inactive but that the presence of a relative excess of lymphocytes over granulocytes tends to inhibit the activity of the granulocyte fraction. It was in fact possible to demonstrate reduction of the activity of granulocyte extracts by the addition of lymphocyte extracts. The results of the latter experiments were quite variable, however, because of the apparently critical ratio of the number of lymphocytes to granulocytes required to effect inhibition.
TABLE IV

Effect of extracts of synovial membranes on viscosity of chondromucoprotein compared with intensity of inflammatory reaclion

\begin{tabular}{|c|c|c|c|c|}
\hline Extract & Source & $\begin{array}{c}\text { Clinical } \\
\text { diagnosis }\end{array}$ & $\begin{array}{l}\text { Inflam- } \\
\text { matory } \\
\text { reaction }\end{array}$ & $\begin{array}{l}\text { Decrease } \\
\text { per hr of } \\
\text { relative } \\
\text { viscosity }\end{array}$ \\
\hline $\begin{array}{l}\text { J. R. } \\
\text { O. B. } \\
\text { K. C. } \\
\text { L. D. } \\
\text { R. K. } \\
\text { J. P. } \\
\text { P. B. } \\
\text { H. B. } \\
\text { M. R. } \\
\text { H. M. }\end{array}$ & $\begin{array}{l}\text { Hip } \\
\text { Hip } \\
\text { Hip } \\
\text { Knee } \\
\text { Hip } \\
\text { Knee } \\
\text { Hip } \\
\text { Knee } \\
\text { Hip } \\
\text { Knee }\end{array}$ & $\begin{array}{l}\text { Rheum. arth. } \\
\text { Rheum. arth. } \\
\text { Rheum. arth. } \\
\text { Rheum. arth. } \\
\text { Ank. spondylitis } \\
\text { Degen. joint dis. } \\
\text { Degen. joint dis. } \\
\text { Degen. joint dis. } \\
\text { Degen. joint dis. } \\
\text { Degen. joint dis. }\end{array}$ & $\begin{array}{l}+++ \\
++ \\
++ \\
\pm \\
0 \\
\pm \\
\pm \\
0 \\
\pm \\
0\end{array}$ & $\begin{array}{r}\% \\
52 \\
50 \\
45 \\
0 \\
0 \\
0 \\
0 \\
0 \\
0 \\
0\end{array}$ \\
\hline
\end{tabular}

\section{DISCUSSION}

Cartilage erosion in rheumatoid arthritis occurs at sites which are in close contact with a highly cellular synovial membrane. The latter is thickened as a result of a marked increase in the number of synovial cells and infiltration by lymphocytes and plasma cells. The resulting synovial pannus becomes an "apron of vascular granulation tissue" which "blends with the superficial layers of cartilage whose cells and substance gradually disappear" (10). Parker and Keefer (11) have concluded, on the basis of histological studies, that the disappearance of the articular cartilage takes place as a result of "solution of the cartilage under the connective tissue that has grown onto the cartilage." Since inflammatory cells of the synovial membrane are presumably in constant turnover, it appears reasonable to suppose that

TABLE V

Viscosity-reducing activity of granulocyte and lymphocyte fractions

\begin{tabular}{|c|c|c|c|}
\hline \multirow[b]{2}{*}{$\begin{array}{c}\text { Experi- } \\
\text { ment }\end{array}$} & \multicolumn{2}{|c|}{ Cells $/ \mathrm{mm}^{2} \times 10^{-2}$} & \multirow{2}{*}{$\begin{array}{l}\text { Decrease } \\
\text { per hr of } \\
\text { relative } \\
\text { viscosity }\end{array}$} \\
\hline & $\begin{array}{c}\text { Granulo- } \\
\text { cytes }\end{array}$ & $\begin{array}{c}\text { Lympho- } \\
\text { cytes }\end{array}$ & \\
\hline no. & $\begin{array}{l}7.8^{*} \\
2.6^{*} \\
1.5 \\
2.3\end{array}$ & $\begin{array}{r}4.0 \\
1.3 \\
16.8 \\
43.7\end{array}$ & $\begin{array}{r}\% \\
52 \\
33 \\
0 \\
0\end{array}$ \\
\hline II & $\begin{array}{l}6.1 \\
1.0 \\
4.0\end{array}$ & $\begin{array}{r}1.1 \\
11.7 \\
45.0\end{array}$ & $\begin{array}{r}45 \\
0 \\
0\end{array}$ \\
\hline
\end{tabular}

* Obtained directly from the dextran-treated whole blood without use of a lucite cylinder. 
enzymes capable of attacking one or more of the constituents of cartilage may be liberated as a result of cellular breakdown.

The demonstration that about half the dry weight of cartilage consists of chondromucoprotein suggested that the lytic action might be well directed against this constituent rather than against collagen, the other major component of cartilage. In favor of this possibility was the absence of known enzymes in the animal body capable of attacking native collagen at neutral $\mathrm{pH}$. Degradation of chondromucoprotein was easily demonstrated in terms of a rapid fall in viscosity of a solution of this protein when it was incubated with extracts of rheumatoid synovial membrane as well as with extracts of leukocytes obtained from the peripheral blood. The decrease in viscosity observed was similar to that obtained with trypsin.

That the reduction in viscosity was due to an enzymatic process appeared likely for a number of reasons. The rate of the reaction increased with the concentration of the extract used and with temperature, and it varied with $\mathrm{pH}$, reaching an optimum at $\mathrm{pH}$ 6.7. The activity was entirely abolished by heating. Formol titration following incubation with both leukocyte and rheumatoid synovial membrane extracts demonstrated liberation of approximately 0.7 per cent of the total nitrogen at the point of 50 per cent reduction in viscosity, while trypsin under similar conditions gave a somewhat higher value. These results suggested that the enzyme or enzymes involved were endopeptidases.

Significant information about the type of proteolysis produced was obtained by filtration of the reaction products through fritted glass bacterial filters. It is known from the work of Shatton and Schubert (1) that the chondromucoprotein is not filterable through this type of funnel, while free chondroitin sulfate is filtered. Treatment of the chondromucoprotein, with extracts of leukocytes as well as with trypsin, did in fact result in the formation of large amounts of filterable material. The split products, which, as formol titration had previously indicated, were relatively large units, appeared to be of two types: one, a fraction rich in hexosamine and low in nitrogen which did not pass through the funnel; the other, a fraction rich in nitrogen and poor in hexosamine which did traverse the filter. Although 20 to 25 per cent of the nitrogen was filtered, less than 4 per cent of the hexosamine behaved similarly.

Although the chondromucoprotein has been observed to be electrophoretically homogenous over a wide range of $\mathrm{pH}$ (12), two components have recently been observed on ultracentrifugal analysis (3). In view of the latter evidence of nonhomogeneity, it is not possible to interpret the relationship of the composition of the hydrolytic products to the structure of the chondromucoprotein substrate.

A linear type of arrangement in which chondroitin sulfate complexes are cemented together in an end to end fashion by protein has been suggested by Muir (4) for a chondroitin sulfateprotein complex isolated from hyaline cartilage. The structure of chondroitin sulfate-protein compelexes has also been discussed by Webber and Bayley (13), Bernardi (14), and Mathews (15). Regardless of the homogeneity and structure of the components of the chondromucoprotein preparation used, it is clear that significant alteration of the chemical and physical properties of the mucoprotein ground substance of cartilage is produced by the various extracts and enzymes studied here and by other workers.

Differences in proteolytic activity between polymorphonucleocytes and lymphocytes have been noted previously. Barnes (16) has reported the presence of a trypsin-like enzyme in cat polymorphonucleocytes which was not present in the lymphocytes of this species. In the present experiments not only were extracts of lymphocyte fractions themselves inactive, but there was evidence that they were, in fact, capable of inhibiting the activity of polymorphonucleocyte extracts. This is strongly suggested by the data in Table $\mathrm{V}$ which show absence of activity in lymphocyte-rich preparations which contain sufficient numbers of polymorphonucleocytes to be otherwise markedly active.

The pronounced proteolytic activity of rheumatoid synovial membrane extracts was related to the cellularity of this tissue-the more highly infiltrated the tissue, the more active the extracts. Since the latter were prepared by homogenization and repeated freezing and thawing, and since extracts from nonrheumatoid synovial membranes were inactive, it would appear that the active enzymes had been extracted from the inflammatory 
cells and possibly from the proliferating synovial cells. In two instances in which the synovial membrane samples, one from a patient with rheumatoid arthritis and the other from a patient with ankylosing spondylitis, showed insignificant cellular infiltration, there was no demonstrable activity.

It is difficult to reconcile the above findings with the observation that extracts obtained from lymphocytes of the peripheral blood were inactive. In view of the paucity of polymorphonucleocytes in the rheumatoid synovial membrane and the presence mainly of lymphocytes, plasma cells, mononuclear cells and proliferating synovial cells, it is difficult to designate the cell type responsible for the activity of the synovial extracts. The problem is complicated by the fact that, although polymorphonucleocytes are not seen in significant number in the rheumatoid synovial membrane, they are released into the synovial fluid where they occur in large numbers in this disease. With regard to the destruction of cartilage in rheumatoid arthritis, which is essentially a slow process, the continuous turnover of even small numbers of granulocytes in the synovial membrane might be sufficient to bring about the changes observed. The activity of the synovial membrane extracts, however, is more likely derived from enzymes extracted from other cell types, such as plasma cells, mononuclear cells or proliferating synovial cells.

It is less difficult, of course, to apply the proposed concept of the mechanism of cartilage destruction to the problem of pyogenic arthritis, since the synovitis in this state is predominantly polymorphonuclear in type. Phemister (17), in a now classic experiment, described the almost complete digestion of articular cartilage on incubation with staphylococcal pus. Phemister concluded that polymorphonucleocytes were the main source of the enzymes responsible for this digestion. When cartilage was incubated with tuberculous pus, on the other hand, the cartilage was unchanged. This was attributed to the presence of lymphocytes rather than to polymorphonucleocytes in tuberculous pus. These early experiments are in good agreement with the results reported in this paper.

An illustration of the in vivo destruction of cartilage by a proteolytic enzyme is seen in the observation of Thomas (18) that the intravenous injection of crude papain into rabbits resulted in collapse of the rabbits' ears and depletion of the basophilic component of the cartilage matrix. The depleted component was presumably the chondromucoprotein since there was a considerable reduction in the chondroitin sulfate content of cartilage following injection of papain (19). A striking example of a disease in which the breakdown of cartilage probably occurs as a result of the action of the enzymes of inflammatory cells is seen in the syndrome, chronic atrophic polychondritis, which has been recently reviewed by Bean, Drevets and Chapman (20). This syndrome is characterized by widespread inflammation and dissolution of cartilage. The inflammatory cells in the cartilage are predominantly polymorphonuclear leukocytes. It seems likely that the dramatic dissolution of cartilage observed in this disease is a result of proteolysis of chondromucoprotein.

A localized type of cartilage necrosis at the site of contact between cartilage and vascular synovial tissue has been described in frostbite by Kulka and Blair (21). Neutrophilic infiltration of the synovial membrane occurred following exposure of rabbit feet to cold. This was followed by accumulation and fragmentation of corpuscular elements in the injured tissues and a subsequent resorption of cartilage.

Lack (22) has recently reported that bovine plasmin is capable of liberating chondroitin sulfate from cartilage slices in vitro. From this observation the author has concluded that plasmin may play a role in the chondrolysis associated with joint infections caused by organisms like the staphylococcus and streptococcus which produce kinases capable of activating plasminogen.

The type of injury to cartilage that has been postulated in the present paper on the basis of proteolysis of chondromucoprotein may be a prototype of similar changes in other kinds of connective tissue. It would be desirable, for example, to establish whether bone has a similar mucoprotein in the osteoid tissue and whether erosion of bone occurs as a result of a similar process.

The experiments reported in this paper have been carried out with bovine chondromucoprotein because human material was not available. It appears reasonable to assume that the bovine protein is a satisfactory model, however, since Schubert (3) has recently prepared chondromucoprotein material from human hyaline cartilage which has 
similar physical and chemical properties to the bovine product. ${ }^{2}$

\section{SUMMARY}

1. Extracts of leukocytes from the peripheral blood and from rheumatoid synovial membranes have been shown to degrade a mucoprotein preparation prepared from bovine hyaline cartilage. The activity of the leukocyte extracts was shown to be derived from the polymorphonucleocyte fraction. The lymphocyte fraction yielded inactive extracts. The activity of human synovial membrane extracts was proportional to the amount of cellular infiltration.

2. The breakdown of the mucoprotein was associated with a marked decrease in viscosity, but only a small fraction of the peptide nitrogen present was liberated. Fractionation of the hydrolytic products indicated that the mucoprotein had been degraded into portions which were relatively high and low in chondroitin sulfate content, respectively. Similar results were obtained with a solution of trypsin. The data suggest that the active agents of the leukocyte extracts studied were endopeptidases.

3. On the basis of the findings presented, it is suggested that the dissolution of cartilage in rheumatoid arthritis and in other inflammatory arthritides is due to degradation of the mucoprotein ground substance of the cartilage by enzymes liberated in the course of breakdown of cells present in the inflamed synovial membrane.

\section{REFERENCES}

1. Shatton, J., and Schubert, M. Isolation of a mucoprotein from cartilage. J. biol. Chem. 1954, 211, 565.

2. Malawista, I., and Schubert, M. Chondromucoprotein: New extraction method and alkaline degradation. J. biol. Chem. 1958, 230, 535.

3. Schubert, M. Personal communication.

4. Muir, H. Nature of link between protein and car-

2 Two samples of chondromucoprotein, prepared from human rib cartilage, were obtained from Dr. Maxwell Schubert and treated with human leukocyte extract in the usual manner. These samples, prepared from the cartilage of individuals of 2 and 17 years of age, respectively, showed falls in viscosity of 32 and 35 per cent over a two hour period. bohydrate of a chondroitin sulphate complex from hyaline cartilage. Biochem. J., 1958, 69, 195.

5. Ziff, M., Gribetz, H. J., and Lospalluto, J. Effects of leucocytes and rheumatoid synovial membrane on the viscosity of a mucoprotein obtained from cartilage (abstract). Ann. rheum. Dis. 1955, 14, 412.

6. Kline, D. L. A modification of Ottesen's method for the separation of granulocytes from lymphocytes. J. Lab. clin. Med. 1955, 46, 781.

7. Schloss, B. Colorimetric determination of glucosamine. Analyt. chem. 1951, 23, 1321.

8. Northrop, J. A. A convenient method for the formol titration. J. gen. Physiol. 1926, 9, 767.

9. Ogston, A. G., and Stanier, J. E. Further observations on the preparation and composition of the hyaluronic acid complex of ox synovial fluid. Biochem. J. 1952, 52, 149.

10. Collins, D. H. The Pathology of Articular and Spinal Diseases. London, Edward Arnold and Co., 1949, p. 183.

11. Parker, F., Jr., and Keefer, C. S. Gross and histologic changes in the knee joint in rheumatoid arthritis. Arch. Path. (Chicago) 1935, $20,507$.

12. Warner, R. C., and Schubert, M. Electrophoretic behavior of chondromucoprotein. J. Amer. chem. Soc. 1958, 80, 5166.

13. Webber, R. V., and Bayley, S. T. Some observations on the molecular form of chondroitin sulphate. Canad. J. Biochem. 1956, 34, 993.

14. Bernardi, G. Size and shape of cartilage mucoprotein. Nature (Lond.) 1957, 180, 93.

15. Mathews, M. B. The molecular weight of sodium chondroitin sulfate by light scattering. Arch. Biochem. 1956, 61, 367.

16. Barnes, J. M. Enzymes of lymphocytes and polymorphonuclear leucocytes. Brit. J. exp. Path. 1940, 21, 264.

17. Phemister, D. The effect of pressure on articular surfaces in pyogenic and tuberculous arthritides, and its bearing on treatment. Ann. Surg. 1924, 80, 481.

18. Thomas, L. Reversible collapse of rabbit ears after intravenous papain, and prevention of recovery by cortisone. J. exp. Med. 1956, 104, 245.

19. Tsaltas, T. T. Papain-induced changes in rabbit cartilage. Alterations in the chemical structure of the cartilage matrix. J. exp. Med. 1958, 108, 507.

20. Bean, W. B., Drevets, C. C., and Chapman, J. S. Chronic atrophic polychondritis. Medicine (Baltimore) $1958,37,353$.

21. Kulka, J. P., and Blair, J. R. Vascular and articular lesions of frost bite. Ann. rheum. Dis. 1956, 15, 380.

22. Lack, C. H. Action of plasmin on cartilage. Nature (Lond.) 1958, 182, 948. 